\title{
Techniques for Maximizing the Performance of Molecular Pathology Testing: Responsibilities of All Pathologists
}

\author{
Evren UZUN ID, SÜLEN SARIOĞLU \\ Department of Pathology, Dokuz Eylül University Faculty of Medicine, IZMIR, TURKEY
}

\begin{abstract}
Molecular pathological analysis has an expanding role in patient diagnosis and management. The performance of these techniques relies on excellent laboratory procedures. However, the crucial step is obtaining the best samples for molecular analysis. Archiving and selection of these are the responsibilities of all pathologists even if they are not working at a center with molecular pathological facilities.

This review focuses on the features of different types of materials for molecular pathological analysis. Many steps that might affect the results, including communication between the pathologist and the oncology team, features of different types of materials (cytological, tissue blocks, biopsy, circulating tumor cells (CTCs) and cell-free circulating nucleic acids), effects of tissue processing, methods for selecting the best material, and tissue saving and tumor enrichment methods are discussed. The procedures for referral to a center for molecular pathological analysis are
\end{abstract} also mentioned.

Awareness of the importance of the cytopathological and histopathological material of the patients for future molecular pathological analysis by pathologists is of the utmost importance.

Key Words: Molecular Pathology, Tissue saving, Tumor enrichment, Tumor percentage

\section{INTRODUCTION}

"Molecular Pathology" is one of the pathological methods with expanding role in patient diagnosis, prediction of prognosis and treatment. Tissue and cellular material from patients have always been valued in pathology laboratories; however they gain additional importance in the molecular pathology era with the increase in new disease classifications according to molecular changes and new targeted therapy options being determined with predictive molecular testing.

While the value of diseased and normal tissue is expanding with the advances in immunohistochemistry and molecular pathology, minimally invasive techniques have taken the place of radical processes in tissue sampling along with developments in the technology. These techniques are better for the comfort of the patient but they also have disadvantages, as they provide smaller amounts of tissue for diagnosis. The management of tissues obtained with these techniques can be problematic for pathologists. The application of individualized treatment regimens developed in recent years has depended on molecular studies. The adequacy of the obtained material and its reliability for molecular investigation are of utmost importance in many cases.

(Turk Patoloji Derg 2018, 34:113-126)

Received : 12.09.2017 Accepted : 06.11.2017
The diagnosis of lung carcinomas is usually made with small biopsies or cytological materials and these materials are generally the only options for further studies. Transthoracic, transbronchial fine needle aspirations, forceps biopsies, bronchial brushes, and washes are some of these materials (1). A molecular examination requires the best process and good sample quality. The most important factor for the success of molecular tests is the number of tumor cells and the percentage of mutant cells (2). The requirements for tumor cell number and mutation percentage differ from method to method but there are minimum requirements and increasing number and percentage correlates with the success of molecular testing as a general rule. The pathologist's view in the past that the primary purpose is tissue diagnosis has changed today to tissue protection as well as tissue diagnosis (3). Errors in tissue management lead to insufficient tissue in addition to the disappointment of the patient and undesirable consequences such as the repetition of invasive procedures and the delay of treatment.

The primary task in the intensive molecular testing process is to prevent tissue wastage. After this step, it is important for the pathologist to select the most appropriate specimen for the procedure, to treat the tissue in such a way as to

Correspondence: Evren UZUN

Dokuz Eylül University Faculty of Medicine,

Department of Pathology, IZMIR, TURKEY

E-mail: drevrenuzun@gmail.com Phone: +90 2324123434 
obtain maximum yield and, if necessary, to increase the proportion of tumor cells (4).

Molecular pathological methods are used in patient diagnosis, determining the prognosis, and predicting the response to treatment. Some of the Pathology departments still do not have any molecular pathological facilities. However, the tissues and cytological samples evaluated in these Pathology laboratories are also prone to undergoing molecular diagnostic procedures at other Pathology laboratories. Even if a pathologist is not providing a molecular pathological diagnosis at present, he/she has to be aware of preanalytical and analytical features that may affect the molecular diagnosis.

In this review, the decision for molecular diagnostic tests, the clues for best practices for patient referral to external molecular laboratories possessing molecular facilities, tissue processing for optimum molecular diagnosis, methods for increasing the adequacy of small biopsies and cytological materials, the approach to material selection for molecular diagnosis in patients with multiple types of materials, methods for increasing tumor cells in the material selected for molecular pathological methods, and the multiple factors affecting the final molecular pathological diagnosis are discussed.

\section{KEY TO SUCCESS IN MOLECULAR PROCESSES: COMMUNICATION}

The most effective and easily correctable factor influencing the success of molecular processing is correct communication. An effective communication process between the clinician, the person transferring the tissue, and the pathology laboratory staff directly affects the success of molecular processes. The inadequacy of this communication can cause lack of information about molecular processing priority, procedure (exposure to formaldehyde for long periods in Friday biopsies or preholiday biopsies), material type, transport conditions, and purpose of the process (3). The clinician who performs the request should communicate with the pathologist regarding the order of priority in the order of preference, and if more than one patient's material is available, which one is appropriate for the procedure. The preliminary material in the archive may be more appropriate for molecular review than the last one in some patients. The pathology laboratory should especially be warned if a gene related to a newly developed resistance is to be studied from the last sent sample (5). The lack of communication may occur within the same institution or between institutions or laboratories, which might be a more frequent problem (3).
This issue will be discussed in more detail at the material referral section.

\section{WHY DO WE GO OVER THINGS WITH A FINE COMB? MINIMUM REQUIREMENTS}

As we mentioned before, a molecular test requires the best process and good sample quality. The use of small biopsies and cytological materials, especially in lung carcinomas, has increased significantly with the development of minimally invasive diagnostic techniques and these materials can sometimes be the sole source for molecular studies. The primary objective is to treat the material obtained with the best technique and preserve the highest quality genetic material. The mutation may be negative if there is no mutation in the tumor cells corresponding to the biopsy specimen or if the tumor cells are inadequate for analysis (6). Non-tumoral cells (epithelial, stromal, inflammatory cells) often dilute the tumor cell ratio, reduce the success rate and sensitivity of molecular assays, and cause false negative results (7). Sensitive methods are indispensable for the success of tumor proportion, albeit with increased sensitivity (8).

There are research articles about the adequacy of materials for molecular analysis. In the study performed by Scarpino and colleagues, the minimum adequate tumor cell number was found to be $140 \pm 34$ tumor cells and the minimum tumor area was $0.12 \mathrm{~mm}^{2}$ in a series of lung adenocarcinoma sections and using these values, $11 / 12$ cases were found to be sufficient for mutation analysis. In the same study, the minimum tumor percentage for Sanger sequencing was 20$30 \%(6)$.

One of the reasons for inconsistent results in molecular pathologic analysis may be the mutant allele ratio. In the study performed by Dijkstra et al. (2), 10 case sets with information about the mutant allele ratio $(2.5,5,10$ and $15 \%)$ were prepared from artificial tissue blocks, from cell lines known to be of the mutant and wild-type, and paraffin blocks. These sets were worked on different platforms; Amplification Refractory Mutation System or AlleleSpecific PCR (ARMS-PCR), High-Resolution Melting (HRM), Sanger, and Pyrosequencing. In all applications, false negative results increased with a decreased mutant allele ratio (2).

\section{WHICH MATERIAL IS MORE SUITABLE?}

Although the most appropriate source for molecular studies is fresh tissue, in theory, FFPE tissues are used as the source in most molecular examinations today (9). Fresh tissues are not always available. The use of FFPE tissues 
(either small biopsy or resection material) in molecular examinations have some advantages; generally sufficient DNA can be obtained, most of the processing stages are standardized, the original primary tumor slide can be stored, immunohistochemistry and in situ hybridization can be performed, the tumor microenvironment can be monitored, and tumor heterogeneity can be observed easily. The disadvantages include semi-invasive or invasive techniques, low repeatability, the effect of formalin on the DNA, and obtaining biopsies from one region in general (primary or metastatic tumor) (10,11).

In recent years, there have been many studies showing that cytological materials are suitable for molecular pathological analysis. Cytological materials that were obtained with easily reproducible and comfortable methods constitute a valuable resource for diagnosis and treatment studies in routine pathological process. Studies have shown that cytological specimens used in molecular studies show up to $100 \%$ compatibility with histological specimens (12). Especially in the majority of non-small cell lung carcinomas, the diagnosis is provided with cytological material and small biopsies. However, the fact that pathologists have information about which cytological specimens and biopsy techniques are more suitable for molecular examinations will increase the success of the procedure. Cytological specimens are examined in two parts, aspiration specimens, and exfoliative specimens. Both have their own advantages and disadvantages (13). Other examples are washing and brushing samples and effusion fluids (1, 14-21).

FNA (fine needle aspiration) samples have the advantages of targeting a specific lesion and minimally invasive processing. Numerous studies have shown that molecular processes are successful on FNA samples $(13,22)$. The samples taken with EUS FNA and EBUS-TBNA in nonsmall cell lung carcinomas were shown to be highly sensitive in EGFR, KRAS mutation and EML-ALK4 translocation assays (23-25). It has been reported that the fluids obtained by these methods are compatible with the histological specimens taken from the same patient $(26,27)$.

Nowadays, molecular studies from aspirations have been successfully applied to the thyroid, lung, pancreas, and gastrointestinal tract lesions (28-34). The smear preparation and cell block prepared from the FNA samples are also suitable sources for the FISH method (35-38). However, there are limiting conditions, including the presence of sufficient number of cells when FISH studies are generally considered positive or negative (39-41).
Due to the loss of cohesion in tumor cells, the fluids obtained with FNA are rich in tumor cells and poor in stromal cells, which is ideal for molecular pathological analysis. FNA samples are used in tissue diagnosis by smearing on a slide or preparing a cell block (26).

The cell block is preferred for DNA extraction. Recent studies have shown that DNA can be extracted by scraping a cytological slide with a performance compatible with a cell block (9). It is even stated that the smears are more successful than cell blocks in terms of tumor cell number and tumor cellularity in some studies. However, cell blocks are preferred by most centers. This is because when the cell block is processed, the section of the original diagnosis can be stored. The cell ratio can be calculated more conveniently and additional studies can be performed $(1,42)$.

It has been shown that after aspiration with a fine needle, enough genetic material can be obtained even from the fluid obtained by washing the needle. The genetic material thus obtained was compared with the genetic material obtained by scraping, and the success in molecular processing was found to be similar (43).

Exfoliative samples were also good sources for molecular studies (44). For high-risk HPV analysis, exfoliated samples are used and these samples are appropriate sources for FISH, PCR and sequencing techniques. Detection of chromosome 3, 7, 9 and 17 anomalies in urine samples with the FISH technique are valuable for tumor patients for follow-up and diagnosis and increase the possibility of bladder cancer detection compared to cytology alone (4547).

Washing and brushing samples exemplify a wide area. Although they appear advantageous, these samples contain a large number of non-tumoral cells, which is disadvantageous for molecular examinations. These samples have been successfully used for lung carcinoma, FISH and other molecular studies $(48,49)$.

Effusion liquids are samples that also contain many cells. However, it is controversial to use them in molecular examinations, as they usually include many nontumor reactive cells. Despite these limitations, there are publications on their successful use in EGFR mutation analysis (50-52). FISH is also used to distinguish malignant mesothelioma and adenocarcinoma from reactive processes or metastatic tumors in effusion fluids (53-57).

A liquid biopsy may be an option when a biopsy or cytology is not available. Blood is the most frequent liquid biopsy material and it may be used for monitoring the 
new mutations during the progression of cancer when managing the patient. The agreement between liquid biopsy specimens and tumor tissue samples in molecular studies ranges from 33to 88\% (58-60). A liquid biopsy is an analysis of circulating tumor cells (CTCs) and cell-free circulating nucleic acids released to the peripheral blood by the primary tumor or metastatic deposits (61-63). The patient's plasma or serum may contain free nucleic acids, complex nucleic acids (within the nucleosome), or nucleic acids in the circulating vesicles (in the exosomes). The ctDNA (circulating tumor DNA) fragments originate from apoptotic and necrotic tumor cells that secrete their DNA into the bloodstream (64).

Various methods have been developed for CTC analysis (65-68). Most of the CTC analysis is based on epithelial markers and CTCs with epithelial-mesenchymal transition may be missed (69).

In the literature, it has been reported that tyrosine kinase inhibitor resistance (70) and EGFR activating mutations have been successfully studied with cells obtained by liquid biopsy (71). It has also been reported that liquid biopsies can be used for KRAS mutation analysis in colon cancer and BRAF mutation analysis in melanoma $(72,73)$.

Advantages compared to tissue biopsy are easy application, noninvasiveness, reproducibility, fast results, genetic material from many regions at the same time in cases with metastasis, and the possibility of detecting intratumoral heterogeneity. Disadvantages are the need for numerous analytical studies, the non-tumoral cell DNA being indistinguishable from the tumor cell DNA, and the free circulation being always small (74).

\section{EFFECT OF LABORATORY PROCESSES ON THE SUCCESS OF MOLECULAR TESTING}

Laboratory procedures applied on the materials also affect the amount and quality of the nucleic acid obtained and the success of the molecular process. These procedures include fixation, preparation (liquid-based cytology, cell block, etc.), staining, mounting medium and de-calcification. The use of decalcification or heavy metal-containing fixatives makes molecular studies difficult or even impossible with the best discourse, either by nucleic acid damage or by inhibiting enzymatic reactions $(15,75)$. Most molecular laboratories do not accept tissue samples exposed to such processes. The success of molecular processes on FFPE tissues and the factors affecting this success are well understood and the differences between cytological preparations are striking.
Fixative-preservative fluid: Long-term storage causes DNA degeneration and protein antigen loss (76). However, the fixation method is especially important for nuclear antigens over the period of storage. Liquid-based cytology is used in gynecological cytology and is also an appropriate source for molecular techniques. Cytorich Blue and Cytorich Red used in liquid-based cytological methods in various studies have been found to be more effective in the protection of DNA that ethanol and formalin fixation (77).

On the contrary, there are publications reporting better protection of DNA by Cytolyt fluid compared with Cytorich and ethanol (21,78). Preservcyt (Cytyc Corporation) is a similar fixative and is an effective agent for long-term storage and protection of nucleic acid for both RNA- and DNA-based studies (79-81).

Preservcyt and Cytolyt solutions are methanol based. Cytorich contains formaldehyde at a rate of less than $1 \%$. The poor results with Cytorich Red can be explained by the presence of formaldehyde because formaldehyde can degrade DNA and lead to modification by cross-linking cytosine residues (82).

It is reported that isopropanol-based sprays used in the rapid fixation of gynecological cytological smears are similar to those fixed with ethanol in the preservation of nucleic acid and better than those dried in air. It has also been shown that liquid-based mounting media maintain DNA better than xylene based ones (78).

Method of cytopreparation: Various cytological preparation methods are available, each of which has advantages and disadvantages. These methods include liquid-based smears, cell blocks, and direct smears.

Liquid-based studies are a popular method for the detection of high-risk HPV in cervical cytology and can be studied from aspiration, exfoliation, and lavage from the thyroid, pancreas, breast and other areas. The material obtained by scraping from liquid-based smears is a successful source for molecular tests (83-91). The advantage of liquid-based studies is that they can be easily applied and put into protective fluid after obtaining the sample, which is necessary for the protection of the nucleic acid, immediately. Furthermore, protective liquids used in liquid-based studies do not cause the problem of DNA degradation in formalin-fixed tissues (92).

The cell block is the best studied and understood specimen for DNA extraction applied for in situ methods and molecular pathology analysis, with similar preparation to surgical specimens and biopsies. One common belief is 
that a cell block can be preferred to biopsy materials for molecular testing. However, it should be noted that the tumor cell ratio can be low in cell blocks even if the total amount of material is high. Tumor enrichment such as microdissection can be applied to cell blocks as for tissue blocks (15).

Although the tumor amount of cell blocks prepared from fine needle aspirations obtained from the lung, pancreas, gastrointestinal tract, soft tissue masses, and similar tissues is very small, clearly successful results are obtained $(1,18,29,31,32,85,93,94)$.

Cell blocks have similar advantages to liquid-based samples. However, a common disadvantage in both the cell block and the liquid-based specimen is that material adequacy cannot be determined immediately. Finally, cell blocks are also exposed to effects such as degradation of the nucleic acid quality that affects the success of molecular tests because they enter formalin fixation and are embedded in paraffin (95-98).

Because of the ability to readily assess the adequacy of the sample and the high quality of nucleic acid, the direct smear is the best material of cytopathology for PCR based studies. High-quality nucleic acids can be obtained for molecular tests, even for archived specimens in both PAP stain and Giemsa stain, which are the two most common stains applied to direct smears (9). Remarkably, the nucleic acid obtained from cytological spreads is of better quality than that obtained from FFPE tissues. This reflects the difference between alcohol fixation and formalin fixation (15).

Staining: The stains applied to cytological preparations can also lead to differences in the genetic material extracted. In two studies comparing FFPE specimens with H\&E stained cell block, PAP stained smears, air-dried smears and thin prep liquid-based smears, PAP stained smears showed the highest success for molecular studies $(78,99)$.

Under this success lies the PAP staining mechanism. Giemsa and PAP staining, which are the two most frequently applied staining methods for cytological preparations, differ in two ways. First difference; while the Pap smear is fixed by alcohol, Giemsa stained preparations are air dried. The second is that the PAP stained smear passes through the hematoxylin staining phase and Giemsa stained smear does not. In addition to the belief that DNA protection power in this area is mainly due to alcohol fixation, there are reports that hematoxylin stain is also effective on genetic material (100-102). On the contrary, there are publications reporting that Giemsa stained smears are more successful than PAP stained ones for the extraction of genetic material (9).

\section{SPECIAL MATERIAL: BONE}

The effects of decalcification on nucleic acids are known and generally make molecular processes impossible. There are several different ways to reduce this negative effect. Soft tissues can be separated from sclerotic tissues and placed in different blocks. In most bone materials with metastatic lesion recognition, the tumor part usually does not require decalcification because most tumors damage the bone structure $(103,104)$.

Another approach is to ask the clinician to apply FNA as much as possible to bone lesions. FNA samples usually do not require decalcification procedures. In a material that has been decalcified in an experimental study conducted in Colorado University, it was reported that as basophilia increases in the bone trabeculae, the reliability of molecular treatment also increases. This is related to the eosinophilic appearance of the fully decalcified bone trabecula while basophilia reflects less extensive decalcification $(103,104)$.

Different decalcification methods also affect the success of the molecular process. For example, in decalcification with ethylenediaminetetraacetic acid (EDTA), more successful results are obtained in molecular processes than in those with a strong acid $(103,104)$. Despite this success in molecular processing, EDTA decalcification is not a widely preferred method. This may be due to longer decalcification time, more frequent solution exchange and higher cost. Successful molecular studies carried out in decalcified samples with the development of technology are reported. Especially in bone samples that were decalcified with formic acid-based agents, molecular pathological analysis can achieve up to $73 \%$ success with NGS (105).

\section{TISSUE SAVING}

Pathologists want to see a full cross-sectional aspect in order to give a tissue diagnosis. This means that the tissue will be shaved until the full cross-sectional aspect is obtained. Especially when more than one tissue is placed on the same block, even more shaving can take place because of the difference in depth. For this reason, it is recommended to place one core per block in tru-cut biopsies and put them in blocks of $1^{\prime} \mathrm{cm}$ in length if the cores are too long (3). In materials consisting of small pieces, no more than 3 pieces should be placed per block (3). Sections of a tissue up to a full cross-sectional view can be a suitable source for molecular studies.

In most pathology laboratories, many techniques are applied, such as "pre-cutting" with the aim of protecting the tissue as much as possible. For this purpose, unstained 
sections and previously requested immunohistochemical studies have been added to the preservation of the tissue. In addition, if the material is referred to the external laboratory, these unstained sections will prevent the repetition of tissue shaving. Nevertheless, as mentioned in material handling, the referral of an H\&E stained section along with the block is a critical step in tissue conservation (15).

Travis et al. highlighted the importance of minimizing the IHC studies in tissue samples to save tissue for molecular pathology diagnosis (106). They stated that although it is generally believed that frequent false negative results occur in small biopsies, this is usually due to excessive tissue shavings. This can be prevented by keeping the immunohistochemical studies at a minimal level.

Immunohistochemical and histochemical assays should be requested at the same time as much as possible. Making requests as separate pieces increases shaving of the tissue block. Use of pre-cut unstained sections for additional studies and, if possible immunohistochemical doublestaining are also tissue saving methods (14).

If only the FNA sample of a patient with a known diagnosis is sent for molecular examination, the cell block should be prepared immediately and the shaving should be limited as much as possible (15).

\section{TUMOR ENRICHMENT}

If there is something more important than the total amount of the sample, it is tumor cellularity defined as the ratio of the nucleated tumoral cells to the nontumoral cells. When this rate is low, it is called tumoral dilution. Therefore, samples that are small but contain many tumor cells are useful for molecular processes compared to a large sample containing few tumor cells.

In these cases with limited material or in materials with a low tumor cell ratio, tumor enrichment should be performed. Tumor enrichment is an important step in the study of molecular pathology because most molecular pathology studies require a minimum tumor/non-tumor cell ratio (3). For cytology samples; tumor enrichment is usually a necessary procedure, often performed under a microscope by scraping through the smear or block (6). The most commonly used methods are macrodissection and/or microdissection. Tumor areas are marked on the $\mathrm{H} \& \mathrm{E}$ stained sections in macro/microdissection, the most common method that most of the histopathologists prefer. Taking this cross-section as a guide, these areas are scraped from the relevant block (Figure 1A-D). Macrodissection is sufficient in some large samples, and detailed microdissection may be necessary for specimens that may be considered particularly small and insufficient (3). If the tumor is heterogeneous, it may be necessary to mark multiple sites in multiple locations (4). As an alternative to macrodissection, a $1 \mathrm{~mm}$ punch can be taken from the marked areas or microdissection can be performed using a tissue counterstain under a stereoscopic microscope. Aisner et al. stated that they used a stereoscopic microscope with 10-micron sections for microdissection in their lab and while 3 or fewer consecutive sections were sufficient for microdissection in resection specimens, a larger number of consecutive sections might be required in smaller specimens (3). A laser capture microdissection method is also described (Emert-Buck et al. 1996), and manual microdissection methods are being investigated and improved (7). However, laser capture microdissection is used mostly for research purposes and is not routinely applicable in molecular pathology (4).

Wu et al. (107) compared the cell transfer technique (CTT) with conventional dissection methods. This technique is based on the marking of the targeted area and dissection with a special medium poured over it (Mount Quick media (Daido Sangyo, Tokyo, Japan). In the relevant study, the DNA extraction method was used for all samples. The agreement between the conventional method and CTT was $81 / 82$ (99\%). The authors suggested that the CTT is practically similar to laser microdissection but easier and cheaper. It is easily applicable in every laboratory and does not require special equipment.

\section{THE ESTIMATION OF TUMOR CELL PERCENTAGE BY PATHOLOGISTS}

One of the reasons for the failure of molecular pathological processing is the incorrect estimation of the tumor cell ratio or number. The interobserver reliability of the estimation of the percentage of tumor cells detected in pathological material varies widely among researchers. One of the main tasks that fall into histopathology evaluation today is to estimate tumor cell ratio, which is influential on the reliability and success of the molecular work to be performed (4). Comprehensive tumor cell counting may possibly yield more reliable numbers, but it is time-consuming. Today, in these cases, rough estimates are often used by histopathologists, and the clinical effects of these estimates are not well known. Lhermitte et al. (8) performed a study with 40-50 investigators, $10 \mathrm{H} \& \mathrm{E}$ virtual sections, and $20 \mathrm{H} \& \mathrm{E}$ conventional sections of the lung and colon tumor specimens. The difference between the lowest and highest tumor cell ratio was found to be $66 \%$. This demonstrates the difference between evaluators in tumor 

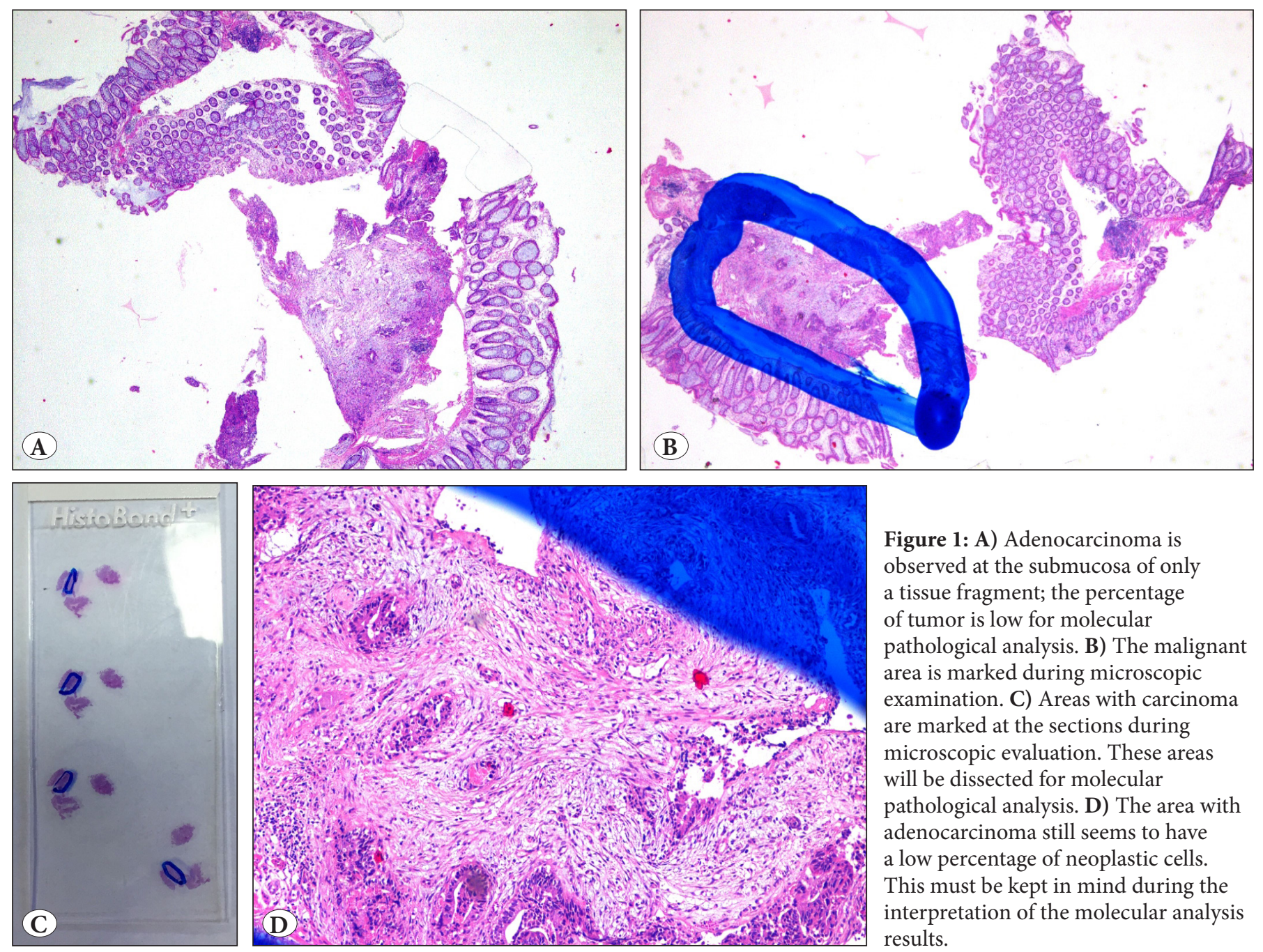

Figure 1: A) Adenocarcinoma is observed at the submucosa of only a tissue fragment; the percentage of tumor is low for molecular pathological analysis. B) The malignant area is marked during microscopic examination. C) Areas with carcinoma are marked at the sections during microscopic evaluation. These areas will be dissected for molecular pathological analysis. D) The area with adenocarcinoma still seems to have a low percentage of neoplastic cells. This must be kept in mind during the interpretation of the molecular analysis results.

cell counting. The most variable samples usually occur in specimens containing dense lymphocytic infiltrates or a mucinous stroma. In a study where the tumor cell ratio was below $20 \%$, this difference was shown to be greater (108). Macrodissection had a reducing effect on the differences between tumor percentage estimations. The reliability of molecular studies increases when tumor cellularity is predicted correctly and especially when heterogeneous tumors are microdissected (8). In practice, how can the accuracy of the tumor cell count be increased? Since tumor cell nuclei are larger than other epithelial, inflammatory and stromal cell nuclei, it would be more appropriate to calculate the ratio of the tumor cell nucleus to the nontumor cell nucleus instead of calculating the area (Figure 2A,B). Making counts through immunohistochemically stained sections can be effective in separating these two cell populations (108).
Travis et al. (106) suggested that tumor cell rates should be calculated by automated methods. Although the effects of over or undercount in most pathology laboratories are unknown, it is appropriate to set up previously known sets of tumor cell numbers and practice on them (108).

\section{MATERIAL REFERRAL}

If a material is referred to an external center for molecular examination, it should first be ensured that the laboratory to be used has national or international accreditation. It is important that the laboratory participates in quality assurance assessment once or twice a year (109).

The type of fixative applied to the material, the duration of fixation, and the additional laboratory procedures (decalcification etc.) applied should be clearly indicated together with the material shipped. If the FFPE block is being sent, a pre-prepared $\mathrm{H} \& \mathrm{E}$ painted cross-section will prevent unnecessary shaving. If the cytological material 

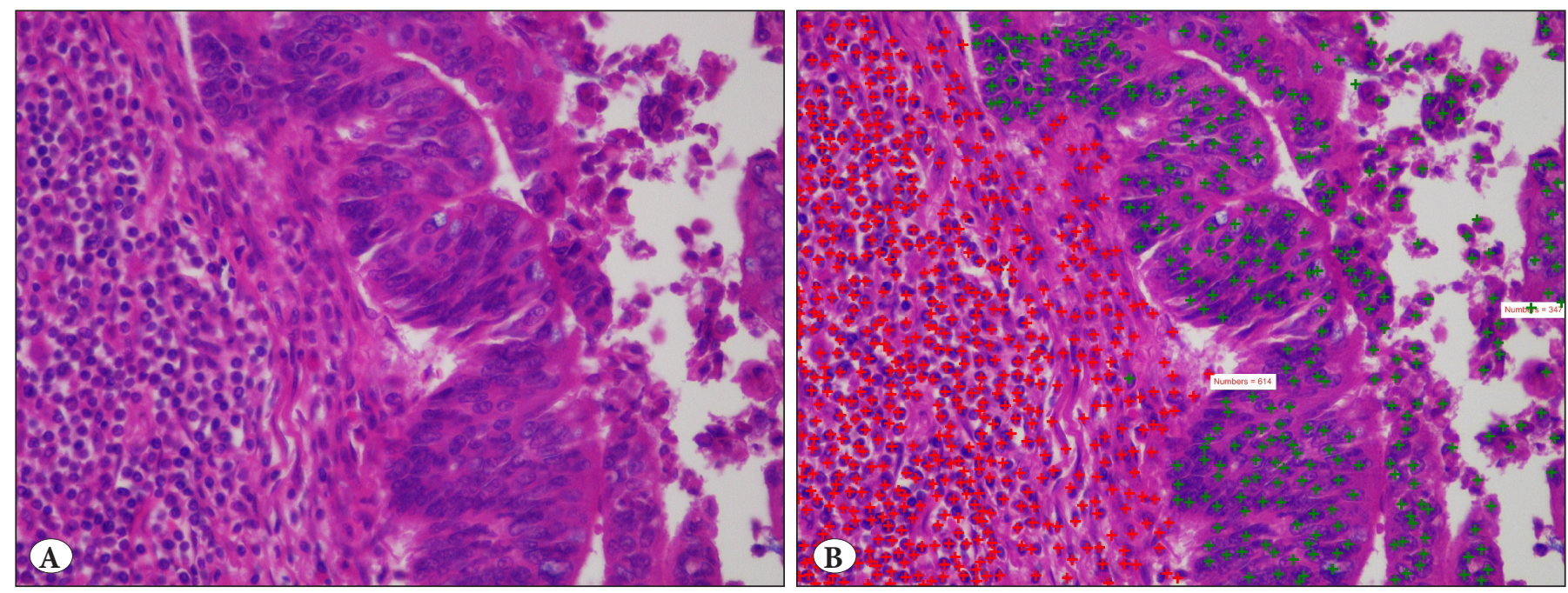

Figure 2: A) Colon adenocarcinoma; half of the area of the image is covered by the neoplastic lesion. B) Nuclei are counted using the image analysis program allowing the pathologist to click to select each point; the adenocarcinoma nuclei count was 347 but the nonneoplastic nuclei count was 614. These image and point counting results highlight the discrepancy between area and tumor nuclei percentage.

is referred, immunohistochemical and histochemical stained smears may provide an additional source of genetic material. If there is more than one material belonging to a patient and it can not be decided which is more appropriate for the molecular tests, it would be appropriate to send all available materials (3). If the pathologist is not familiar with molecular pathological analysis prerequisites, it would be the best practice to send all the available material including cytological samples to a center with molecular pathology facilities.

\section{REFLEX TESTING}

In most centers, molecular testing is requested by the clinical team, especially by the oncologist. However, a pathologist or cytopathologist who has information about the stage of the disease may be more effective in applying molecular tests reflexively without the need for a request by an oncologist. The reflex test reduces cost as well as time loss and prevents possible delayed treatment (110). In one study, it was shown that the reflex test reduced the Mean “Time To Treatment" From 36 Days To 26 Days (111).

\section{WHAT IS IN THE FUTURE?}

Along with the increase in targeted treatment options, the number of molecular tests applied to establish treatment options is also increasing. Molecular investigations in large panels, especially in lesser quantities, reduce the success of the studies. For this purpose, it is important to develop various platforms, especially NGS, which simultaneously detect multiple mutations in the same sample (112-116).
Moreover, the specific sample requirements of NGS and fully automated platforms force pathologists to develop new methods of preparing specific preparations. With the technological advances in NGS, allele-specific real-time PCR technology is also developing rapidly. NGS provides pathologists with an advantage in the reliability and the availability of materials that are valid for cytological specimens.

NGS is a validated technology for both tissue biopsy and cytology specimens. Metastatic lesions may have different characteristics from the primary tumor, and biopsies may not give an idea of all of the tumor due to tumor heterogeneity. This can lead to mismanagement of the patient (117). Although the studies started 20 years ago, liquid biopsies, which have accelerated with the development of NGS technology, may overcome these contradictions (118). Although CTC studies are generally performed on carcinomas, studies on primary brain tumors have also been reported (119). Today, ultra-sensitive technologies have been developed that can work with DNA fragments at very low concentrations (120). Some of these technologies are based on the segregation of malignant and benign tumor cells cytomorphologically from nonhematological circulating cells (65-67). Methods based on size-specific discrimination of epithelial tumor cells are also used (65-67). A new approach is to work with xenograft CTCs by producing CTC-derived transplants. In this way, we can have options such as testing the treatments or having information about the mechanism of drug resistance (121, 122). CTC assays can provide reliable information on 
prognosis as well as help to identify new therapeutic targets. Obtaining genetic material from both the primary tumor and metastatic deposits at the same time may be of benefit in our understanding of tumor heterogeneity (123). At this stage, sequential administration of CTC analyzes before, during, and after treatment can provide information about tumor progression and possible resistance mechanisms $(73,124,125)$.

\section{CONCLUSION}

In summary, the success of any molecular process depends on many factors. Standardization of preanalytical protocols at this stage is both successful and increases reliability. These protocols include communication, testing, sampling, fixation, tissue handling, staining, tumor enrichment, DNA quality and quantity determination and storage. Each of the molecular laboratories needs to standardize these protocols depending on their capabilities and capacities. Pathologists and cytopathologists working at centers that cannot perform molecular examinations must establish common protocols with molecular laboratories regarding material referral.

In recent years, with targeted treatment agents beginning to be used in traditional treatment, molecular studies have become a must for pathology. The awareness of expert pathologists, cytopathologists, and other pathology laboratory staff about the importance of the relationship between histopathology procedures and the performance of molecular techniques will reduce human-induced errors in molecular pathology analysis.

\section{REFERENCES}

1. da Cunha Santos G, Saieg MA, Geddie W, Leighl N. EGFR gene status in cytological samples of nonsmall cell lung carcinoma: Controversies and opportunities. Cancer Cytopathol. 2011;119:80-91.

2. Dijkstra JR, Heideman DA, Meijer GA, Boers JE, 't Hart NA, Diebold J, Hirschmann A, Hoefler G, Winter G, MiltenbergerMiltenyi G, Pereira SV, Richman SD, Quirke P, Rouleau EL, Guinebretiere JM, Tejpar S, Biesmans B, van Krieken JH. KRAS mutation analysis on low percentage of colon cancer cells: The importance of quality assurance. Virchows Arch. 2013;462:3946

3. Aisner DL, Rumery MD, Merrick DT, Kondo KL, Nijmeh $\mathrm{H}$, Linderman DJ, Doebele RC, Thomas N, Chesnut PC, VarellaGarcia M, Franklin WA, Camidge DR. Do more with less: Tips and techniques for maximizing small biopsy and cytology specimens for molecular and ancillary testing: The University of Colorado Experience. Arch Pathol Lab Med. 2016 Sep 9. [Epub ahead of print]
4. Cree IA, Deans Z, Ligtenberg MJ, Normanno N, Edsjo A, Rouleau E, Solé F, Thunnissen E, Timens W, Schuuring E, Dequeker E, Murray S, Dietel M, Groenen P, Van Krieken JH; European Society of Pathology Task Force on Quality Assurance in Molecular Pathology; Royal College of Pathologists. Guidance for laboratories performing molecular pathology for cancer patients. J Clin Pathol. 2014;67:923-31.

5. Arcila ME, Oxnard GR, Nafa K, Riely GJ, Solomon SB, Zakowski MF, Kris MG, Pao W, Miller VA, Ladanyi M. Rebiopsy of lung cancer patients with acquired resistance to EGFR inhibitors and enhanced detection of the T790M mutation using a locked nucleic acid-based assay. Clin Cancer Res. 2011;17:1169-80.

6. Scarpino S, Pulcini F, Di Napoli A, Giubettini M, Ruco L. EGFR mutation testing in pulmonary adenocarcinoma: Evaluation of tumor cell number and tumor percent in paraffin sections of 120 small biopsies. Lung Cancer. 2015;87:8-13.

7. Huang Q, Sacks PG, Mo J, McCormick SA, Iacob CE, Guo L, Schaefer S, Schantz SP. A simple method for fixation and microdissection of frozen fresh tissue sections for molecular cytogenetic analysis of cancers. Biotech Histochem. 2005;80:14756.

8. Lhermitte B, Egele C, Weingartner N, Ambrosetti D, Dadone B, Kubiniek V, Burel-Vandenbos F, Coyne J, Michiels JF, Chenard MP, Rouleau E, Sabourin JC, Bellocq JP. Adequately defining tumor cell proportion in tissue samples for molecular testing improves interobserver reproducibility of its assessment. Virchows Arch. 2017;470:21-7.

9. Killian JK, Walker RL, Suuriniemi M, Jones L, Scurci S, Singh P, Cornelison R, Harmon S, Boisvert N, Zhu J, Wang Y, Bilke S, Davis S, Giaccone G, Smith WI Jr, Meltzer PS. Archival fine-needle aspiration cytopathology (FNAC) samples: An untapped resource for clinical molecular profiling. J Mol Diagn. 2010;12:739-45.

10. Hofman P, Popper HH. Pathologists and liquid biopsies: To be or not to be? Virchows Arch. 2016;469:601-9.

11. Suciu BA, Pap Z, Denes L, Brinzaniuc K, Copotoiu C, Pavai Z. Allele-specific PCR method for identification of EGFR mutations in non-small cell lung cancer: Formalin-fixed paraffin-embedded tissue versus fresh tissue. Rom J Morphol Embryol. 2016;57:495-500.

12. Gailey MP, Stence AA, Jensen CS, Ma D. Multiplatform comparison of molecular oncology tests performed on cytology specimens and formalin-fixed, paraffin-embedded tissue. Cancer Cytopathol. 2015;123:30-9.

13. Krishnamurthy S. Applications of molecular techniques to fineneedle aspiration biopsy. Cancer. 2007;111:106-22.

14. Aisner DL, Marshall CB. Molecular pathology of non-small cell lung cancer: A practical guide. Am J Clin Pathol. 2012;138:332 46.

15. Aisner DL, Sams SB. The role of cytology specimens in molecular testing of solid tumors: Techniques, limitations, and opportunities. Diagn Cytopathol. 2012;40:511-24.

16. Witt BL, Wallander ML, Layfield LJ, Hirschowitz S. Respiratory cytology in the era of molecular diagnostics: A review. Diagn Cytopathol. 2012;40:556-63. 
17. Malapelle U, Bellevicine C, Zeppa P, Palombini L, Troncone G. Cytology-based gene mutation tests to predict response to anti-epidermal growth factor receptor therapy: A review. Diagn Cytopathol. 2011;39:703-10.

18. Rekhtman N, Brandt SM, Sigel CS, Friedlander MA, Riely GJ, Travis WD, Zakowski MF, Moreira AL. Suitability of thoracic cytology for new therapeutic paradigms in non-small cell lung carcinoma: High accuracy of tumor subtyping and feasibility of EGFR and KRAS molecular testing. J Thorac Oncol. 2011;6:4518.

19. Aisner DL, Deshpande C, Baloch Z, Watt CD, Litzky LA, Malhotra B, Sepulveda AR, Langer C, Evans T, Van Deerlin VM. Evaluation of EGFR mutation status in cytology specimens: An institutional experience. Diagn Cytopathol. 2013;41:316-23.

20. Betz BL, Roh MH, Weigelin HC, Placido JB, Schmidt LA, Farmen S, Arenberg DA, Kalemkerian GP, Knoepp SM. The application of molecular diagnostic studies interrogating EGFR and KRAS mutations to stained cytologic smears of lung carcinoma. Am J Clin Pathol. 2011;136:564-71.

21. Malapelle U, de Rosa N, Rocco D, Bellevicine C, Crispino C, Illiano A, Piantedosi FV, Nappi O, Troncone G. EGFR and KRAS mutations detection on lung cancer liquid-based cytology: A pilot study. J Clin Pathol. 2012;65:87-91.

22. Lewandowska MA, Jozwicki W, Jochymski C, Kowalewski J. Application of PCR methods to evaluate EGFR, KRAS and BRAF mutations in a small number of tumor cells in cytological material from lung cancer patients. Oncol Rep. 2013;30:1045-52.

23. van der Heijden HFM, Looijen-Salamon MG, Schuurbiers OCJ, Bussink J, Ligtenberg MJL. EBUS and EUS guided fine needle aspirations for molecular diagnostic analysis in lung cancer. Thorac Cancer. 2012;3:201-6.

24. van Eijk R, Licht J, Schrumpf M, Talebian Yazdi M, Ruano D, Forte GI, Nederlof PM, Veselic M, Rabe KF, Annema JT, Smit V, Morreau H, van Wezel T. Rapid KRAS, EGFR, BRAF and PIK3CA mutation analysis of fine needle aspirates from nonsmall-cell lung cancer using allele-specific qPCR. PLoS One. 2011;6:e17791.

25. Rafael OC, Aziz M, Raftopoulos H, Vele OE, Xu W, Sugrue C. Molecular testing in lung cancer: Fine-needle aspiration specimen adequacy and test prioritization prior to the CAP/ IASLC/AMP Molecular Testing Guideline publication. Cancer Cytopathol. 2014;122:454-8.

26. Bozzetti C, Negri FV, Azzoni C, Naldi N, Nizzoli R, Bortesi B, Zobbi V, Bottarelli L, Tiseo M, Silini EM, Ardizzoni A. Epidermal growth factor receptor and Kras gene expression: Reliability of mutational analysis on cytological samples. Diagn Cytopathol. 2013;41:595-8.

27. Li W, Zhang Z, Guo L, Qiu T, Ling Y, Cao J, Guo H, Zhao H, Li L, Ying J. Assessment of cytology-based molecular analysis to guide targeted therapy in advanced non-small-cell lung cancer. Oncotarget. 2016;7:8332-40.

28. Apple SK, Hecht JR, Novak JM, Nieberg RK, Rosenthal DL, Grody WW. Polymerase chain reaction-based K-ras mutation detection of pancreatic adenocarcinoma in routine cytology smears. Am J Clin Pathol. 1996;105:321-6.
29. Rader AE, Avery A, Wait CL, McGreevey LS, Faigel D, Heinrich MC. Fine-needle aspiration biopsy diagnosis of gastrointestinal stromal tumors using morphology, immunocytochemistry, and mutational analysis of c-kit. Cancer. 2001;93:269-75.

30. Schenk T, Ackermann J, Brunner C, Schenk P, Zojer N, Roka S, Drach J. Detection of chromosomal aneuploidy by interphase fluorescence in situ hybridization in bronchoscopically gained cells from lung cancer patients. Chest. 1997;111:1691-6.

31. Shih JY, Gow CH, Yu CJ, Yang CH, Chang YL, Tsai MF, Hsu YC, Chen KY, Su WP, Yang PC. Epidermal growth factor receptor mutations in needle biopsy/aspiration samples predict response to gefitinib therapy and survival of patients with advanced nonsmall cell lung cancer. Int J Cancer. 2006;118:963-9.

32. Willmore C, Holden JA, Zhou L, Tripp S, Wittwer CT, Layfield LJ. Detection of c-kit-activating mutations in gastrointestinal stromal tumors by high-resolution amplicon melting analysis. Am J Clin Pathol. 2004;122:206-16.

33. Abati A, Sanjuan X, Wilder A, Linehan WM, Hewitt SM, Merino MJ. Utilization of microdissection and the polymerase chain reaction for the diagnosis of adrenal cortical carcinoma in fine-needle aspiration cytology. Cancer. 1999;87:231-7.

34. Beaty MW, Zhuang Z, Park WS, Emmert-Buck MR, Linehan WM, Lubensky IA, Abati A. Fine-needle aspiration of metastatic clear cell carcinoma of the kidney: Employment of microdissection and the polymerase chain reaction as a potential diagnostic tool. Cancer. 1997;81:180-6.

35. Jiang F, Katz RL. Use of interphase fluorescence in situ hybridization as a powerful diagnostic tool in cytology. Diagn Mol Pathol. 2002;11:47-57.

36. Cajulis RS, Frias-Hidvegi D, Yu GH, Eggena S. Detection of numerical chromosomal abnormalities by fluorescence in situ hybridization of interphase cell nuclei with chromosomespecific probes on archival cytologic samples. Diagnostic Cytopathol. 1996;14:178-81.

37. Nizzoli R, Guazzi A, Naldi N, Fraciosi V, Bozzetti C. HER-2/neu evaluation by fluorescence in situ hybridization on destained cytologic smears from primary and metastatic breast cancer. Acta Cytol. 2005;49:27-30.

38. Bozzetti C, Personeni N, Nizzoli R, Guazzi A, Flora M, Bassano C, Negri F, Martella E, Naldi N, Franciosi V, Cascinu S. HER$2 /$ neu amplification by fluorescence in situ hybridization in cytologic samples from distant metastatic sites of breast carcinoma. Cancer. 2003;99:310-5.

39. Bozzetti C, Nizzoli R, Guazzi A, Flora M, Bassano C, Crafa P, Naldi N, Cascinu S. HER-2/neu amplification detected by fluorescence in situ hybridization in fine needle aspirates from primary breast cancer. Ann Oncol. 2002;13:1398-403.

40. Kapila K, Al-Awadhi S, Francis I. Her-2 neu (Cerb-B2) expression in fine needle aspiration samples of breast carcinoma: A pilot study comparing FISH, CISH and immunocytochemistry. J Cytol. 2011;28:54-6.

41. Beatty BG, Bryant R, Wang W, Ashikaga T, Gibson PC, Leiman G, Weaver DL. HER-2/neu detection in fine-needle aspirates of breast cancer: Fluorescence in situ hybridization and immunocytochemical analysis. Am J Clin Pathol. 2004;122:24655. 
42. Sun PL, Jin Y, Kim H, Lee CT, Jheon S, Chung JH. High concordance of EGFR mutation status between histologic and corresponding cytologic specimens of lung adenocarcinomas. Cancer Cytopathol. 2013;121:311-9.

43. Bozzetti C, Naldi N, Nizzoli R, Azzoni C, Bortesi B, Zobbi V, Bottarelli L, Tiseo M, Gasparro D, Majori M, De Filippo M, Ardizzoni A. Reliability of EGFR and KRAS mutation analysis on fine-needle aspiration washing in non-small cell lung cancer. Lung Cancer. 2013;80:35-8.

44. Arentsen HC, de la Rosette JJ, de Reijke TM, Langbein S. Fluorescence in situ hybridization: A multitarget approach in diagnosis and management of urothelial cancer. Expert Rev Mol Diagn. 2007;7:11-9.

45. Gibson J, Young S, Leng B, Zreik R, Rao A. Molecular diagnostic testing of cytology specimens: Current applications and future considerations. Journal of the American Society of Cytopathology. 2014;3:280-94.

46. Halling KC, Kipp BR. Bladder cancer detection using FISH (UroVysion assay). Adv Anat Pathol. 2008;15:279-86.

47. Sarosdy MF, Kahn PR, Ziffer MD, Love WR, Barkin J, Abara EO, Jansz K, Bridge JA, Johansson SL, Persons DL, Gibson JS. Use of a multitarget fluorescence in situ hybridization assay to diagnose bladder cancer in patients with hematuria. J Urol. 2006; 176:44-7.

48. Yamaguchi K, Nakano K, Nagai E, Chijiiwa K, Kinoshita M, Ohta M, Tanaka M. Ki-ras mutations in codon 12 and p53 mutations (biomarkers) and cytology in bile in patients with hepatobiliary-pancreatic carcinoma. Hepatogastroenterology. 2005;52:713-8.

49. Yamashita K, Kuba T, Shinoda H, Takahashi E, Okayasu I. Detection of K-ras point mutations in the supernatants of peritoneal and pleural effusions for diagnosis complementary to cytologic examination. Am J Clin Pathol. 1998;109:704-11.

50. Hung MS, Lin CK, Leu SW, Wu MY, Tsai YH, Yang CT. Epidermal growth factor receptor mutations in cells from nonsmall cell lung cancer malignant pleural effusions. Chang Gung Med J. 2006;29:373-9.

51. Jian G, Songwen Z, Ling Z, Qinfang D, Jie Z, Liang T, Caicun $Z$. Prediction of epidermal growth factor receptor mutations in the plasma/pleural effusion to efficacy of gefitinib treatment in advanced non-small cell lung cancer. J Cancer Res Clin Oncol. 2010;136:1341-7.

52. Kimura H, Fujiwara Y, Sone T, Kunitoh H, Tamura T, Kasahara K, Nishio K. EGFR mutation status in tumour-derived DNA from pleural effusion fluid is a practical basis for predicting the response to gefitinib. Br J Cancer. 2006;95:1390-5.

53. Fiegl M, Massoner A, Haun M, Sturm W, Kaufmann H, Hack R, Krugmann J, Fritzer-Szekeres M, Grünewald K, Gastl G. Sensitive detection of tumour cells in effusions by combining cytology and fluorescence in situ hybridisation (FISH). Br J Cancer. 2004;91:558-63.

54. Fiegl M, Kaufmann H, Zojer N, Schuster R, Wiener H, Mullauer L, Roka S, Huber H, Drach J. Malignant cell detection by fluorescence in situ hybridization (FISH) in effusions from patients with carcinoma. Hum Pathol. 2000;31:448-55.
55. Zojer N, Fiegl M, Angerler J, Mullauer L, Gsur A, Roka S, Pecherstorfer M, Huber H, Drach J. Interphase fluorescence in situ hybridization improves the detection of malignant cells in effusions from breast cancer patients. Br J Cancer. 1997;75:4037.

56. Savic S, Franco N, Grilli B, Barascud Ade V, Herzog M, Bode B, Loosli H, Spieler P, Schönegg R, Zlobec I, Clark DP, Herman JG, Bubendorf L. Fluorescence in situ hybridization in the definitive diagnosis of malignant mesothelioma in effusion cytology. Chest. 2010;138:137-44

57. Chung CT, Santos Gda C, Hwang DM, Ludkovski O, Pintilie M, Squire JA, Tsao MS. FISH assay development for the detection of p16/CDKN2A deletion in malignant pleural mesothelioma. J Clin Pathol. 2010;63:630-4.

58. Brevet M, Johnson ML, Azzoli CG, Ladanyi M. Detection of EGFR mutations in plasma DNA from lung cancer patients by mass spectrometry genotyping is predictive of tumor EGFR status and response to EGFR inhibitors. Lung Cancer. 2011;73:96-102.

59. Nakamura T, Sueoka-Aragane N, Iwanaga K, Sato A, Komiya K, Kobayashi N, Hayashi S, Hosomi T, Hirai M, Sueoka E Kimura S. Application of a highly sensitive detection system for epidermal growth factor receptor mutations in plasma DNA. J Thorac Oncol. 2012;7:1369-81.

60. Bai H, Mao L, Wang HS, Zhao J, Yang L, An TT, Wang X, Duan CJ, Wu NM, Guo ZQ, Liu YX, Liu HN, Wang YY, Wang J. Epidermal growth factor receptor mutations in plasma DNA samples predict tumor response in Chinese patients with stages IIIB to IV non-small-cell lung cancer. J Clin Oncol. 2009;27:2653-9.

61. Alix-Panabieres C, Pantel K. Circulating tumor cells: Liquid biopsy of cancer. Clin Chem. 2013;59:110-8.

62. Pantel K, Alix-Panabieres C. Real-time liquid biopsy in cancer patients: Fact or fiction? Cancer Res. 2013;73:6384-8.

63. Schwarzenbach H, Nishida N, Calin GA, Pantel K. Clinical relevance of circulating cell-free microRNAs in cancer. Nat Rev Clin Oncol. 2014;11:145-56.

64. Schwarzenbach H, Hoon DS, Pantel K. Cell-free nucleic acids as biomarkers in cancer patients. Nat Rev Cancer. 2011;11:426-37.

65. Hofman V, Bonnetaud C, Ilie MI, Vielh P, Vignaud JM, Flejou JF, Lantuejoul S, Piaton E, Mourad N, Butori C, Selva E, Poudenx M, Sibon S, Kelhef S, Vénissac N, Jais JP, Mouroux J, Molina TJ, Hofman P. Preoperative circulating tumor cell detection using the isolation by size of epithelial tumor cell method for patients with lung cancer is a new prognostic biomarker. Clin Cancer Res. 2011;17:827-35.

66. Hofman V, Long E, Ilie M, Bonnetaud C, Vignaud JM, Flejou JF, Lantuejoul S, Piaton E, Mourad N, Butori C, Selva E, Marquette $\mathrm{CH}$, Poudenx M, Sibon S, Kelhef S, Vénissac N, Jais JP, Mouroux J, Molina TJ, Vielh P, Hofman P. Morphological analysis of circulating tumour cells in patients undergoing surgery for nonsmall cell lung carcinoma using the isolation by size of epithelial tumour cell (ISET) method. Cytopathology. 2012;23:30-8.

67. Ferreira MM, Ramani VC, Jeffrey SS. Circulating tumor cell technologies. Mol Oncol. 2016;10:374-94. 
68. Paterlini-Brechot P, Benali NL. Circulating tumor cells (CTC) detection: Clinical impact and future directions. Cancer Lett. 2007;253:180-204.

69. Yokobori $\mathrm{T}$, Iinuma $\mathrm{H}$, Shimamura $\mathrm{T}$, Imoto $\mathrm{S}$, Sugimachi $\mathrm{K}$, Ishii $\mathrm{H}$, Iwatsuki $\mathrm{M}$, Ota $\mathrm{D}$, Ohkuma $\mathrm{M}$, Iwaya $\mathrm{T}$, Nishida $\mathrm{N}$, Kogo R, Sudo T, Tanaka F, Shibata K, Toh H, Sato T, Barnard GF, Fukagawa T, Yamamoto S, Nakanishi H, Sasaki S, Miyano S, Watanabe T, Kuwano H, Mimori K, Pantel K, Mori M. Plastin3 is a novel marker for circulating tumor cells undergoing the epithelial-mesenchymal transition and is associated with colorectal cancer prognosis. Cancer Res. 2013;73:2059-69.

70. Tan CS, Cho BC, Soo RA. Next-generation epidermal growth factor receptor tyrosine kinase inhibitors in epidermal growth factor receptor -mutant non-small cell lung cancer. Lung Cancer. 2016;93:59-68.

71. Lin CC, Huang WL, Wei F, Su WC, Wong DT. Emerging platforms using liquid biopsy to detect EGFR mutations in lung cancer. Expert Rev Mol Diagn. 2015;15:1427-40.

72. Chang GA, Tadepalli JS, Shao Y, Zhang Y, Weiss S, Robinson E, Spittle C, Furtado M, Shelton DN, Karlin-Neumann G, Pavlick A, Osman I, Polsky D. Sensitivity of plasma BRAFmutant and NRASmutant cell-free DNA assays to detect metastatic melanoma in patients with low RECIST scores and non-RECIST disease progression. Mol Oncol. 2016;10:157-65.

73. Siravegna G, Bardelli A. Blood circulating tumor DNA for non-invasive genotyping of colon cancer patients. Mol Oncol. 2016;10:475-80.

74. Pantel K, Alix-Panabieres C. Liquid biopsy: Potential and challenges. Mol Oncol. 2016;10:371-3.

75. Hunt JL. Molecular pathology in anatomic pathology practice: A review of basic principles. Arch Pathol Lab Med. 2008;132:24860.

76. Canfell K, Gray W, Snijders P, Murray C, Tipper S, Drinkwater $\mathrm{K}$, Beral V. Factors predicting successful DNA recovery from archival cervical smear samples. Cytopathology. 2004;15:276-82.

77. Kawahara A, Taira T, Abe H, Watari K, Murakami Y, Fukumitsu C, Takase Y, Yamaguchi T, Azuma K, Akiba J, Ono M, Kage M. Fixation effect of SurePath preservative fluids using epidermal growth factor receptor mutation-specific antibodies for immunocytochemistry. Cancer Cytopathol. 2014;122:145-52.

78. Dejmek A, Zendehrokh N, Tomaszewska M, Edsjo A. Preparation of DNA from the cytological material: Effects of fixation, staining, and mounting medium on DNA yield and quality. Cancer Cytopathol. 2013;121:344-53.

79. Monsonego J, Autillo-Touati A, Bergeron C, Dachez R, Liaras J, Saurel J, Zerat L, Chatelain P, Mottot C. Liquid-based cytology for primary cervical cancer screening: A multi-center study. Br J Cancer. 2001;84:360-6.

80. Keegan H, Boland C, Malkin A, Griffin M, Ryan F, Lambkin H. Comparison of DNA extraction from cervical cells collected in PreservCyt solution for the amplification of Chlamydia trachomatis. Cytopathology. 2005;16:82-7.

81. Tarkowski TA, Rajeevan MS, Lee DR, Unger ER. Improved detection of viral RNA isolated from liquid-based cytology samples. Mol Diagn. 2001;6:125-30.
82. Rait VK, Zhang Q, Fabris D, Mason JT, O’Leary TJ. Conversions of formaldehyde-modified 2'-deoxyadenosine 5'-monophosphate in conditions modeling formalin-fixed tissue dehydration. J Histochem Cytochem. 2006;54:301-10.

83. Cantara S, Capezzone M, Marchisotta S, Capuano S, Busonero G, Toti P, Di Santo A, Caruso G, Carli AF, Brilli L, Montanaro A, Pacini F. Impact of proto-oncogene mutation detection in cytological specimens from thyroid nodules improves the diagnostic accuracy of cytology. J Clin Endocrinol Metab. 2010;95:1365-9.

84. Chudova D, Wilde JI, Wang ET, Wang H, Rabbee N, Egidio CM, Reynolds J, Tom E, Pagan M, Rigl CT, Friedman L, Wang CC, Lanman RB, Zeiger M, Kebebew E, Rosai J, Fellegara G, LiVolsi VA, Kennedy GC. Molecular classification of thyroid nodules using high-dimensionality genomic data. J Clin Endocrinol Metab. 2010;95:5296-304.

85. Dillon DA, Hipolito E, Zheng K, Rimm DL, Costa JC. p53 mutations as tumor markers in fine needle aspirates of palpable breast masses. Acta Cytol. 2002;46:841-7.

86. Hubbard RA. Human papillomavirus testing methods. Arch Pathol Lab Med. 2003;127(8):940-5.

87. Nikiforov YE, Steward DL, Robinson-Smith TM, Haugen BR, Klopper JP, Zhu Z, Fagin JA, Falciglia M, Weber K, Nikiforova $\mathrm{MN}$. Molecular testing for mutations in improving the fineneedle aspiration diagnosis of thyroid nodules. J Clin Endocrinol Metab. 2009;94:2092-8.

88. Nishino HT, Tambouret RH, Wilbur DC. Testing for human papillomavirus in cervical cancer screening: A review of indications and methodology. Cancer Cytopathol. 2011;119:21927.

89. Tisserand P, Fouquet C, Marck V, Mallard C, Fabre M, Vielh P, Soussi T. ThinPrep-processed fine-needle samples of the breast are an effective material for RNA- and DNA-based molecular diagnosis: Application to p53 mutation analysis. Cancer. 2003;99:223-32.

90. Kipp BR, Fritcher EG, Clayton AC, Gores GJ, Roberts LR, Zhang J, Levy MJ, Halling KC. Comparison of KRAS mutation analysis and FISH for detecting pancreatobiliary tract cancer in cytology specimens collected during endoscopic retrograde cholangiopancreatography. J Mol Diagn. 2010;12:780-6.

91. Pugliese V, Pujic N, Saccomanno S, Gatteschi B, Pera C, Aste H, Ferrara GB, Nicolò G. Pancreatic intraductal sampling during ERCP in patients with chronic pancreatitis and pancreatic cancer: Cytologic studies and k-ras-2 codon 12 molecular analysis in 47 cases. Gastrointest Endosc. 2001;54:595-9.

92. von Smolinski D, Leverkoehne I, von Samson-Himmelstjerna $\mathrm{G}$, Gruber AD. Impact of formalin-fixation and paraffinembedding on the ratio between mRNA copy numbers of differently expressed genes. Histochem Cell Biol. 2005;124:17788 .

93. Kilpatrick SE, Cappellari JO, Bos GD, Gold SH, Ward WG. Is fine-needle aspiration biopsy a practical alternative to open biopsy for the primary diagnosis of sarcoma? Experience with 140 patients. Am J Clin Pathol. 2001;115:59-68.

94. Clark DP. Seize the opportunity: Underutilization of fine-needle aspiration biopsy to inform targeted cancer therapy decisions. Cancer. 2009;117:289-97. 
95. Greer CE, Peterson SL, Kiviat NB, Manos MM. PCR amplification from paraffin-embedded tissues. Effects of fixative and fixation time. Am J Clin Pathol. 1991;95:117-24.

96. Srinivasan M, Sedmak D, Jewell S. Effect of fixatives and tissue processing on the content and integrity of nucleic acids. Am J Pathol. 2002;161:1961-71.

97. Ben-Ezra J, Johnson DA, Rossi J, Cook N, Wu A. Effect of fixation on the amplification of nucleic acids from paraffinembedded material by the polymerase chain reaction. J Histochem Cytochem. 1991;39:351-4.

98. Williams C, Ponten F, Moberg C, Soderkvist P, Uhlen M, Ponten J, Sitbon G, Lundeberg J. A high frequency of sequence alterations is due to formalin fixation of archival specimens. Am J Pathol. 1999;155:1467-71.

99. Vivero M, Wang CI, Jo VY, Hollowell M, Cibas ES, Lindeman NI, Lowe AC. Molecular testing of different cytologic preparations in patients with advanced lung adenocarcinoma: Which yields the best results? Journal of the American Society of Cytopathology. 2017;6:16-23.

100. Burton MP, Schneider BG, Brown R, Escamilla-Ponce N, Gulley ML. Comparison of histologic stains for use in PCR analysis of microdissected, paraffin-embedded tissues. BioTechniques. 1998;24(1):86-92.

101. Kmiec Z. J.A. Kiernan. Histological and Histochemical Methods: Theory and Practice. 5th edition, Scion Publishing, 2015, 571 pp. Folia Histochem Cytobiol. 2016;54:58-9.

102. Murase T, Inagaki H, Eimoto T. Influence of histochemical and immunohistochemical stains on polymerase chain reaction. Mod Pathol. 2000;13:147-51.

103. Choi SE, Hong SW, Yoon SO. Proposal of an appropriate decalcification method of bone marrow biopsy specimens in the era of expanding genetic molecular study. J Pathol Transl Med. 2015;49:236-42.

104. Bass BP, Engel KB, Greytak SR, Moore HM. A review of preanalytical factors affecting molecular, protein, and morphological analysis of formalin-fixed, paraffin-embedded (FFPE) tissue: How well do you know your FFPE specimen? Arch Pathol Lab Med. 2014;138:1520-30.

105. Goswami RS, Luthra R, Singh RR, Patel KP, Routbort MJ, Aldape KD, Yao H, Dang HD, Barkoh BA, Manekia J, Medeiros LJ, RoyChowdhuri S, Stewart J, Broaddus RR, Chen H. Identification of factors affecting the success of next-generation sequencing testing in solid tumors. Am J Clin Pathol. 2016;145:222-37.

106. Travis WD, Brambilla E, Noguchi M, Nicholson AG, Geisinger KR, Yatabe Y, Beer DG, Powell CA, Riely GJ, Van Schil PE, Garg K, Austin JH, Asamura H, Rusch VW, Hirsch FR, Scagliotti G, Mitsudomi T, Huber RM, Ishikawa Y, Jett J, Sanchez-Cespedes M, Sculier JP, Takahashi T, Tsuboi M, Vansteenkiste J, Wistuba I, Yang PC, Aberle D, Brambilla C, Flieder D, Franklin W, Gazdar A, Gould M, Hasleton P, Henderson D, Johnson B, Johnson D, Kerr K, Kuriyama K, Lee JS, Miller VA, Petersen I, Roggli V, Rosell R, Saijo N, Thunnissen E, Tsao M, Yankelewitz D. International Association for the study of lung cancer/American thoracic society/European respiratory society international multidisciplinary classification of lung adenocarcinoma. J Thorac Oncol. 2011;6:244-85.
107. Wu HH, Jovonovich SM, Randolph M, Post KM, Sen JD, Curless $\mathrm{K}$, Cheng L. Utilization of cell-transfer technique for molecular testing on hematoxylin-eosin-stained sections: A viable option for small biopsies that lack tumor tissues in paraffin block. Arch Pathol Lab Med. 2016;140:1383-9.

108. Smits AJ, Kummer JA, de Bruin PC, Bol M, van den Tweel JG, Seldenrijk KA, Willems SM, Offerhaus GJ, de Weger RA, van Diest PJ, Vink A. The estimation of tumor cell percentage for molecular testing by pathologists is not accurate. Mod Pathol. 2014;27:168-74.

109. Karapetis CS, Khambata-Ford S, Jonker DJ, O’Callaghan CJ, Tu D, Tebbutt NC, Simes RJ, Chalchal H, Shapiro JD, Robitaille S, Price TJ, Shepherd L, Au HJ, Langer C, Moore MJ, Zalcberg JR. K-ras mutations and benefit from cetuximab in advanced colorectal cancer. N Engl J Med. 2008;359:1757-65.

110. Van Cutsem E, Kohne CH, Hitre E, Zaluski J, Chang Chien CR, Makhson A, D'Haens G, Pintér T, Lim R, Bodoky G, Roh JK, Folprecht G, Ruff P, Stroh C, Tejpar S, Schlichting M, Nippgen J, Rougier P. Cetuximab and chemotherapy as initial treatment for metastatic colorectal cancer. N Engl J Med. 2009;360:1408-17.

111. Cheema PK, Menjak IB, Winterton-Perks Z, Raphael S, Cheng SY, Verma S, Muinuddin A, Freedman R, Toor N, Perera J, Anaka M, Victor JC. Impact of Reflex EGFR/ ALK Testing on time to treatment of patients with advanced nonsquamous nonsmall-cell lung cancer. J Oncol Pract. 2017;13:e130-e138.

112. Su Z, Dias-Santagata D, Duke M, Hutchinson K, Lin YL, Borger $\mathrm{DR}$, Chung $\mathrm{CH}$, Massion PP, Vnencak-Jones CL, Iafrate AJ, Pao W. A platform for rapid detection of multiple oncogenic mutations with relevance to targeted therapy in non-small-cell lung cancer. J Mol Diagn. 2011;13:74-84.

113. Dias-Santagata D, Akhavanfard S, David SS, Vernovsky K, Kuhlmann G, Boisvert SL, Stubbs H, McDermott U, Settleman J, Kwak EL, Clark JW, Isakoff SJ, Sequist LV, Engelman JA, Lynch TJ, Haber DA, Louis DN, Ellisen LW, Borger DR, Iafrate AJ. Rapid targeted mutational analysis of human tumours: A clinical platform to guide personalized cancer medicine. EMBO Mol Med. 2010;2:146-58.

114. Beadling C, Heinrich MC, Warrick A, Forbes EM, Nelson D, Justusson E, Levine J, Neff TL, Patterson J, Presnell A, McKinley A, Winter LJ, Dewey C, Harlow A, Barney O, Druker BJ, Schuff KG, Corless CL. Multiplex mutation screening by mass spectrometry evaluation of 820 cases from a personalized cancer medicine registry. J Mol Diagn. 2011;13:504-13.

115. Fumagalli D, Gavin PG, Taniyama Y, Kim SI, Choi HJ, Paik $S$, Pogue-Geile KL. A rapid, sensitive, reproducible and costeffective method for mutation profiling of colon cancer and metastatic lymph nodes. BMC Cancer. 2010;10:101.

116. Lurkin I, Stoehr R, Hurst CD, van Tilborg AA, Knowles MA, Hartmann A, Zwarthoff EC. Two multiplex assays that simultaneously identify 22 possible mutation sites in the KRAS, BRAF, NRAS and PIK3CA genes. PLoS One. 2010;5:e8802.

117. Gerlinger M, Norton L, Swanton C. Acquired resistance to crizotinib from a mutation in CD74-ROS1. N Engl J Med. 2013;369:1172-3. 
118. Diaz LA Jr, Williams RT, Wu J, Kinde I, Hecht JR, Berlin J, Allen B, Bozic I, Reiter JG, Nowak MA, Kinzler KW, Oliner KS, Vogelstein B. The molecular evolution of acquired resistance to targeted EGFR blockade in colorectal cancers. Nature. 2012;486:537-40.

119. Muller C, Holtschmidt J, Auer M, Heitzer E, Lamszus K, Schulte A, Matschke J, Langer-Freitag S, Gasch C, Stoupiec M, Mauermann O, Peine S, Glatzel M, Speicher MR, Geigl JB, Westphal M, Pantel K, Riethdorf S. Hematogenous dissemination of glioblastoma multiforme. Sci Transl Med. 2014;6:247ra101.

120. Newman AM, Bratman SV, To J, Wynne JF, Eclov NC, Modlin LA, Liu CL, Neal JW, Wakelee HA, Merritt RE, Shrager JB, Loo BW Jr, Alizadeh AA, Diehn M. An ultrasensitive method for quantitating circulating tumor DNA with broad patient coverage. Nat Med. 2014;20:548-54.

121. Hodgkinson CL, Morrow CJ, Li Y, Metcalf RL, Rothwell DG, Trapani F, Polanski R, Burt DJ, Simpson KL, Morris K, Pepper SD, Nonaka D, Greystoke A, Kelly P, Bola B, Krebs MG, Antonello J, Ayub M, Faulkner S, Priest L, Carter L, Tate C, Miller CJ, Blackhall F, Brady G, Dive C. Tumorigenicity and genetic profiling of circulating tumor cells in small-cell lung cancer. Nat Med. 2014;20:897-903.
122. Morrow CJ, Trapani F, Metcalf RL, Bertolini G, Hodgkinson CL, Khandelwal G, Kelly P, Galvin M, Carter L, Simpson KL, Williamson S, Wirth C, Simms N, Frankliln L, Frese KK, Rothwell DG, Nonaka D, Miller CJ, Brady G, Blackhall FH, Dive C. Tumourigenic non-small-cell lung cancer mesenchymal circulating tumour cells: A clinical case study. Ann Oncol. 2016;27:1155-60.

123. Alix-Panabieres C, Pantel K. The circulating tumor cells: Liquid biopsy of cancer. Klin Lab Diagn. 2014:60-4.

124. Bidard FC, Peeters DJ, Fehm T, Nole F, Gisbert-Criado R, Mavroudis D, Grisanti S, Generali D, Garcia-Saenz JA, Stebbing J, Caldas C, Gazzaniga P, Manso L, Zamarchi R, de Lascoiti AF, De Mattos-Arruda L, Ignatiadis M, Lebofsky R, van Laere SJ, MeierStiegen F, Sandri MT, Vidal-Martinez J, Politaki E, Consoli F, Bottini A, Diaz-Rubio E, Krell J, Dawson SJ, Raimondi C, Rutten A, Janni W, Munzone E, Carañana V, Agelaki S, Almici C, Dirix L, Solomayer EF, Zorzino L, Johannes H, Reis-Filho JS, Pantel K, Pierga JY, Michiels S. Clinical validity of circulating tumour cells in patients with metastatic breast cancer: A pooled analysis of individual patient data. Lancet Oncol. 2014;15:406-14.

125. Dawson SJ, Tsui DW, Murtaza M, Biggs H, Rueda OM, Chin SF, Dunning MJ, Gale D, Forshew T, Mahler-Araujo B, Rajan S, Humphray S, Becq J, Halsall D, Wallis M, Bentley D, Caldas C, Rosenfeld N. Analysis of circulating tumor DNA to monitor metastatic breast cancer. N Engl J Med. 2013;368:1199-209. 